\title{
'Monod' and 'air crescent' sign in aspergilloma
}

\author{
Sourabh Sharma, ${ }^{1}$ Sumit Kumar Dubey, ${ }^{1}$ Naveen Kumar, $^{1}$ Deepak Sundriyal ${ }^{2}$
}

1 Department of Medicine, PGIMER \& Dr Ram Manohar Lohia Hospital, New Delhi, India

${ }^{2}$ Department of Medical Oncology, Dharamshila Hospital, New Delhi, India

\section{Correspondence to}

Dr Naveen Kumar,

docnaveen2605@yahoo.co.in
To cite: Sharma $S$

Dubey SK, Kumar N, et al. BMJ Case Rep Published online: [please include Day Month Year] doi:10.1136/ bcr-2013-200936

\section{DESCRIPTION}

A 62-year-old male patient presented with a symptom of haemoptysis for 15 days. There was history of pulmonary Koch's for which he took complete treatment 11 years ago. In the CT scan of the chest, there was an irregular-shaped cavity in the right apical zone, with an oval-shaped mass within it (figure 1). The mass was separated from the wall of the cavity by a crescent-shaped airspace; it is known as an 'air crescent sign'. ${ }^{1}$ This finding is typical of aspergilloma, but is also found in pulmonary tuberculosis, hydatid cyst, pulmonary abscess, bronchogenic carcinoma and Pneumocystis carinii pneumonia. ${ }^{1}$ In aspergilloma, this mass usually moves within the cavity when the patient changes the position and the sign is called a 'Monod sign'. A CT scan of the chest was also performed in the prone position, where it was seen to have moved to the dependent area thus confirming the diagnosis (figure 2).

Aspergilloma occurs in patients with normal immunity with pre-existing cavities. Most commonly they colonise cavity secondary to pulmonary tuberculosis; later accounts for $25-80 \%$ of cases depending on its prevalence in the population. ${ }^{2}$ Most aspergillomas are asymptomatic. The cavity is essentially isolated, and systemic administration of antifungal does not have much role. They need expectant management with close follow-up. ${ }^{3}$ Haemoptysis secondary to reactive vascular granulation tissue is the most common presentation. For brisk haemoptysis, an angiography and a selective bronchial artery embolisation can be life-saving. But if it fails, or in cases of recurrent haemoptysis, surgical excision remains the gold standard. ${ }^{2}$ As this patient was having haemoptysis, he was referred to the Cardio Thoracic Vascular Surgery department. He was discharged after symptomatic treatment and antifungal therapy. He again had massive haemoptysis 1 month later, was admitted

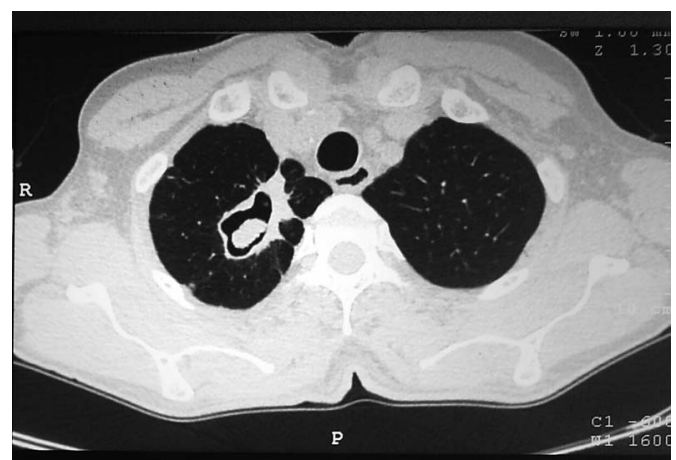

Figure 1 Contrast-enhanced CT of chest showing irregular shape, thick wall cavity with oval shape mass. A crescent-shaped airspace separates the mass from cavity wall, known as air crescent sign.

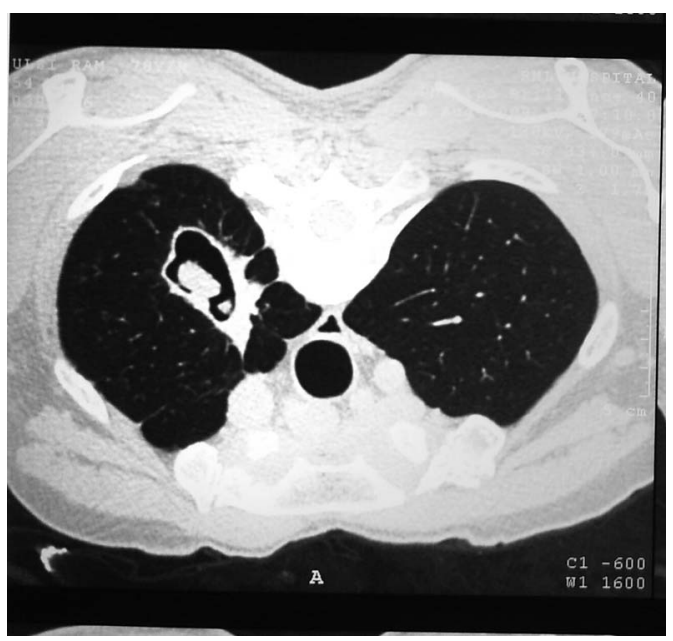

Figure 2 Contrast-enhanced CT of chest in the prone position shows the mass moving to dependent region of the cavity, known as Monod sign.

and a lobectomy was performed as a permanent treatment. The patient survived.

\section{Learning points}

- In patients with a background history of tuberculosis, presenting with haemoptysis, fungal infection should always be kept in differential diagnosis.

- A CT scan for mass in lung cavity should be performed in the supine as well as in the prone position. It helps in differentiating a moving fungal ball from other conditions as mentioned above.

- Aspergilloma should be treated early and aggressively, especially in elderly patients.

Contributors SS, SKD and NK managed the patient. Concept of paper, article drafting, revision and final approval of the article was done by SS, SKD, NK and DS. The data collection was carried out by SS and SKD. Data analysis was done by SS, SKD and DS.

\section{Competing interests None.}

Patient consent Obtained.

Provenance and peer review Not commissioned; externally peer reviewed.

\section{REFERENCES}

1 Franquet T, Muller NL, Gimenez A, et al. Spectrum of pulmonary aspergillosis: histologic, clinical, and radiologic findings. Radiographics 2001;21:825-37.

2 Chen JC, Chang YL, Luh SP, et al. Surgical treatment for pulmonary aspergilloma: a 28 year experience. Thorax 1997;52:810-13.

3 Seaton A. Actinomycotic and fungal diseases. In: Seaton A, Seaton D, Leitch AG.eds Crofton and Douglas's respiratory disease. London: Blackwell Science Ltd, 2002:573-603. 
Copyright 2013 BMJ Publishing Group. All rights reserved. For permission to reuse any of this content visit http://group.bmj.com/group/rights-licensing/permissions.

BMJ Case Report Fellows may re-use this article for personal use and teaching without any further permission.

Become a Fellow of BMJ Case Reports today and you can:

- Submit as many cases as you like

- Enjoy fast sympathetic peer review and rapid publication of accepted articles

- Access all the published articles

- Re-use any of the published material for personal use and teaching without further permission

For information on Institutional Fellowships contact consortiasales@bmjgroup.com

Visit casereports.bmj.com for more articles like this and to become a Fellow 